\title{
Effect of Aging Treatment on Surface Roughness, Mechanical Properties, and Fracture Behavior of 6xxx and 7xxx Aluminum Alloys
}

\author{
I. Sevim, ${ }^{\mathrm{a}, 1}$ S. Sahih, ${ }^{\mathrm{b}}$ H. Cug, ${ }^{\mathrm{c}}$ E. Cevik, ${ }^{\mathrm{c}}$ F. Hayat, ${ }^{\mathrm{c}}$ and M. Karali ${ }^{\mathrm{d}, 2}$ \\ ${ }^{a}$ Department of Mechanical Engineering, Engineering Faculty, Mersin University, Mersin, Turkey \\ b Metallurgy Materials Engineering Department, Engineering Faculty, Kirikkale University, Kirikkale, \\ Turkey \\ ${ }^{\mathrm{c}}$ Metallurgy Materials Engineering Department, Engineering Faculty, Karabuk University Baliklarkayasi, \\ Karabuk, Turkey \\ ${ }^{\mathrm{d}}$ Department of Machine Education, Faculty of Technical Education, Karabuk University, Karabuk, \\ Turkey \\ 1 isevim@mersin.edu.tr \\ 2 mkarali@karabuk.edu.tr
}

УДК 539.4

\section{Влияние процесса старения на шероховатость поверхности, механические свойства и поведение алюминиевых сплавов 6хxх и 7хxx при разрушении}

\author{
И. Севим ${ }^{\mathrm{a}, 1}$, С. Сахин ${ }^{\sigma}$, Х. Чуг ${ }^{\mathrm{B}}$, Е. Чевик ${ }^{\mathrm{B}}$, Ф. Хаят ${ }^{\mathrm{B}}$, М. Карали ${ }^{\mathrm{r}, 2}$

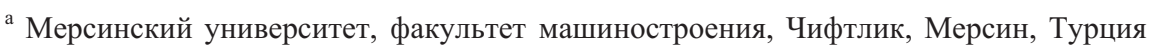 \\ ${ }^{\sigma}$ Кафедра металлургии и материаловедения, факультет машиностроения, Университет Кырык- \\ кале, Кырыккале, Турция \\ в Кафедра металлургии и материаловедения, факультет машиностроения, Университет Карабука, \\ Карабук, Турция \\ г Факультет профессионально-технического образования, Университет Карабука, Карабук, \\ Турция
}

Исследовано влияние прочесса старения на шероховатость поверхности и механические свойства алюминиевых сплавов АА6061 и АА7075. Механические свойства исследовали при испьттаниях на микротвердость и растяжение. Поверхность образцов исследовали с помощью рентгеноструктурного анализа. После испьтания на растяжение поверхность разрушения исследовали методом растровой электронной микроскопии. Влияние процесса старения на шероховатость поверхности изучали с помощью атомно-силового микроскопа. Показано, что с ростом шероховатости поверхности увеличивается количество выделивиихся фаз.

Ключевые слова: алюминиевые сплавы, атомно-силовой микроскоп, механические свойства, растровая электронная микроскопия.

Introduction. Aluminum alloys offering high strength-to-weight ratio, good formidability and high corrosion resistance are extensively used in various fields such as the aerospace and automobile industries [1-8]. Magnesium alloys, the lightest of the structural metals with a two-thirds density of aluminum alloys, have been extensively explored for practical industrial applications during the past decade [9-11]. The high strength-to-weight ratio makes utilization of $6 \mathrm{xxx}$ series $\mathrm{Al}$ alloys favorable for a wide variety of applications [10-14]. Various structural applications in automobile and aerospace 
industries also constitute one of common usage areas of these alloys [4]. These alloys are also out of widely-used materials in architectural applications, bicycle frames, transportation equipment, bridge railings and welded structures. Thus, making estimation related to their mechanical properties is necessary to assure their safe service. Alloys in the 6xxx series contain silicon and magnesium approximately in the proportions required for the formation of magnesium silicide $\left(\mathrm{Mg}_{2} \mathrm{Si}\right)$, which makes them heat-treatable [10]. 7xxx series aluminum alloys, on the other hand, are zinc- and copper-added alloys. Some other elements such as magnesium chrome and zirconium may constitute the content of these alloys having a high strength. Accordingly, in the aerospace sector and other applications requiring a high strength, they are preferred. The AA7075 (Al- $\mathrm{Zn}-\mathrm{Mg}-\mathrm{Cu})$ aluminum alloy is one of the strongest aluminum alloys in industrial use today [14-17]. Its high strength-to weight ratio, together with its natural aging characteristics, makes it attractive for a certain number of aircraft structural applications. The alloy owes its strength to precipitation of $\mathrm{Mg}_{2} \mathrm{Zn}$ and $\mathrm{Al}_{2} \mathrm{CuMg}$ phases $[18,19]$. Providing high strength and capability to being exposed to the heat treatment, $2 \mathrm{xxx}, 6 \mathrm{xxx}$, and 7xxx series alloys are generally used in external structural parts that are exposed to aerodynamic loads. Heat treatments that are conducted, in order to increase the strength of aluminum alloys, are composed of three steps: (i) solution treatment; dissolution of phases (forming the solid solution), (ii) quenching; forming the supersaturated structure, and (iii) aging; precipitation of dissolved atoms at room temperature or higher temperatures (precipitation hardening).

This study is focused on the effect of precipitation hardening (aging) treatment on surface roughness and mechanical properties of $6 \mathrm{xxx}$ and $7 \mathrm{xxx}$ aluminum alloys. For this purpose, the atomic force microscope (AFM) was used for measurement of surface roughness of the specimens which were prepared in accordance with standard metallographic procedures.

Analysis of the mechanical properties of the specimens was performed via conduction of hardness and tensile tests. Additionally, ductility properties and fracture behavior of the specimens fractured due to the tensile test were analyzed by applying a scanning electron microscope (SEM) to their fracture surfaces.

Experimental Procedure. The commercial AA6061 (T6) and AA7075 (T651) alloy were used in this study. Dimensions of the sheets were $300 \times 300 \times 2 \mathrm{~mm}$. Table 1 illustrates the chemical composition of AA6061 and AA7075 alloys.

$\mathrm{T}$ a b 1 e 1

Chemical Composition of the Materials Used in the Experiments

\begin{tabular}{|c|c|c|c|c|c|c|c|c|c|c||}
\hline Material & $\mathrm{Si}$ & $\mathrm{Zn}$ & $\mathrm{Mg}$ & $\mathrm{Cu}$ & $\mathrm{Fe}$ & $\mathrm{Ni}$ & $\mathrm{Mn}$ & $\mathrm{Cr}$ & $\mathrm{V}$ & $\mathrm{Al}$ \\
\hline AA6061 & 0.61 & 0.081 & 0.92 & 0.25 & 0.20 & 0.001 & 0.07 & 0.097 & 0.016 & 97.7 \\
\hline AA7075 & 0.09 & 5.620 & 2.12 & 1.78 & 0.28 & 0.001 & 0.08 & 0.190 & 0.044 & 89.8 \\
\hline
\end{tabular}

AA6061 and AA7075 alloys were cut into $20 \mathrm{~mm}$ length at first, and then 15 specimens were obtained. In order to preserve the supersaturated solid solution at room temperature, all of the specimens of the AA6061 and AA7075 alloys, were exposed to solution heat treatment at 525 and $480^{\circ} \mathrm{C}$ for $4 \mathrm{~h}$ followed by quenching in water at room temperature. After solution heat treatment, all of the specimens of the AA6061 and AA7075 alloys were kept in a freezer, which was very crucial to avoid the natural aging of the alloy at room temperature. Afterwards, the specimens of the AA6061 alloy were artificially age-hardened at $140-185-220^{\circ} \mathrm{C}$ for $1,4,10,14$, and $24 \mathrm{~h}$ periods of time in a furnace and subsequently cooled in air. The AA7075 alloy specimens were artificially age-hardened at $120-155-185^{\circ} \mathrm{C}$ for $1,4,10,14$, and $24 \mathrm{~h}$ periods of time in a furnace and subsequently cooled in air (Table 2). 
The Effect of Aging Treatment ...

$\mathrm{T}$ a b 1 e 2

The Aging Parameters of Materials Used in the Experiments

\begin{tabular}{|c|c|c|c|c|}
\hline Material & Taking solution & Giving water & $\begin{array}{l}\text { Aging thermal } \\
\text { process }\left({ }^{\circ} \mathrm{C}\right)\end{array}$ & Aging time (h) \\
\hline AA6061 & $520^{\circ} \mathrm{C} / 2 \mathrm{~h}$ & $\begin{array}{c}\text { Room } \\
\text { temperature } \\
\left(20^{\circ} \mathrm{C}\right)\end{array}$ & $\begin{array}{l}140 \\
180 \\
220\end{array}$ & $\begin{array}{c}1 \\
4 \\
10 \\
14 \\
24\end{array}$ \\
\hline AA7075 & $480^{\circ} \mathrm{C} / 2 \mathrm{~h}$ & & $\begin{array}{l}120 \\
155 \\
185\end{array}$ & $\begin{array}{c}1 \\
4 \\
10 \\
14 \\
24\end{array}$ \\
\hline
\end{tabular}

The hardness values were measured using a Micro Vickers Hardness Testing Machine with a $200 \mathrm{~g}$ load. the mean value of four hardness readings performed per specimen was calculated.

In order to determine the tensile shear load bearing capacity (TLBC) of aged materials, one set of three test specimens was prepared according to the standards. The TLBC of welded materials was determined by using microprocessor controlled universal testing machine. After tensile tests, the fracture surfaces were analyzed by the SEM.

Furthermore, in order to analyze the effect of aging treatment on surface properties, AFM was used. Surface properties of Al alloys exposed to the aging treatment had been investigated with the AFM. Analysis of residues on the surface via the light microscope was used to provide three-dimensional determination. In the analysis conducted with AFM, the specimens were etched in an etching solution $\left(2.5 \mathrm{ml} \mathrm{HNO}_{3}, 1.5 \mathrm{ml} \mathrm{HCl}, 1 \mathrm{ml} \mathrm{HF}\right.$, and $95 \mathrm{ml}$ distilled water) then exposed to standard metallographic procedures. Specimens were polished by means of a polishing machine by using a $1 \mu \mathrm{m}$ grade felt. The surfaces obtained under these conditions were analyzed with the AFM.

Results and Discussion. The results of this study, the AA6061 and AA7075 alloys were solution-treated at two different temperatures of 480 and $520^{\circ} \mathrm{C}$. After this process, the specimens were aged at three different temperatures (AA6061: 140, 180, and $220^{\circ} \mathrm{C}$ and AA7075: 120,155 , and $\left.185^{\circ} \mathrm{C}\right)$ for five different periods of time $(1,4,10,14$, and $24 \mathrm{~h})$ as seen in Table 2.

X-ray Diffraction Study. The results of X-ray diffraction (XRD) analysis of the original and aged specimens are given in Fig. 1. The aging process resulted in two different intermetallics for AA6061 and AA7075 were determined. $\mathrm{Cu}_{3} \mathrm{Zn}, \mathrm{Al} 0.403 \mathrm{Zn} 0.597 \mathrm{Al} 0.58$ $\mathrm{Mg} 0.42$ for $\mathrm{AA} 6061$ specimens and $\mathrm{Cu}_{3} \mathrm{Zn}, \mathrm{A} 10.403 \mathrm{Zn} 0.597$, and $\mathrm{A} 10.58 \mathrm{Mg} 0.42$ for AA7075 specimens were observed.

Atomic Force Microscopy Study. The graphs plotted as a result of the analysis conducted with the AFM are presented in Fig. 2. In order to analyze the effect of the aging treatment on surface roughness, the specimens were exposed to standard metallographic procedures for equal periods. Surfaces of materials are worn with harder materials. Intermetallic phase is a hard and brittle phase, the abrasives used in preparing metallographic surfaces could wear Al grains more easily. The principle of obtaining a hard secondary phase by means of heat treatment is based on the aging treatment. As stated in literature studies, hard secondary phases occurring in the experiments are $\mathrm{Mg}_{2} \mathrm{Si}$ phase for AA6061 and $\mathrm{Mg}_{2} \mathrm{Zn}$ and $\mathrm{Al}_{2} \mathrm{CuMg}$ intermetallic phases for AA7075[10, 18-20]. Accordingly, as the 


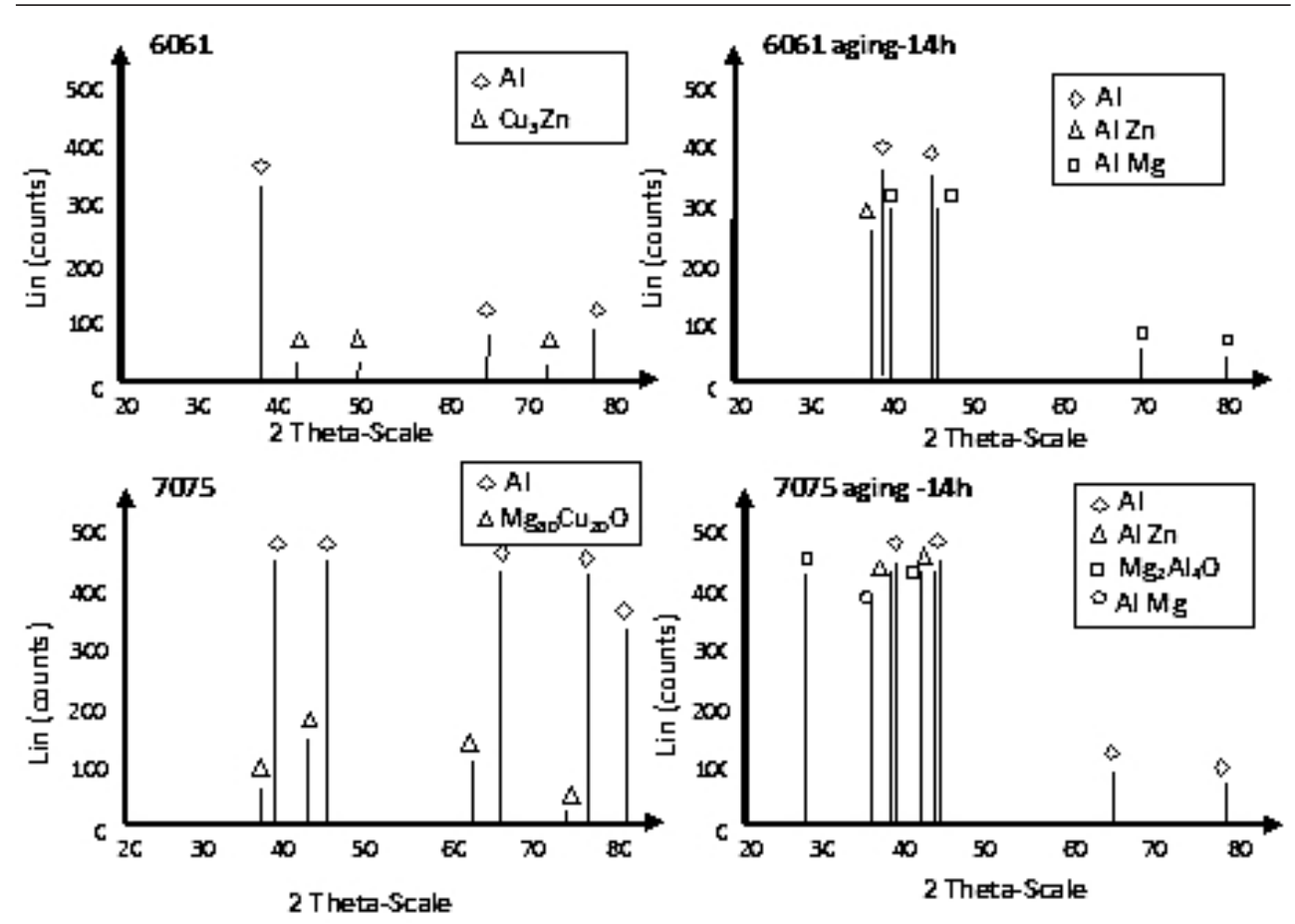

Fig. 1. The XRD analysis of the original and aged specimens.

intermetallic phases increase in the structure, occurrence of rougher surfaces is an expected result. Images obtained with the AFM demonstrate that the specimen of AA6061 aged at $185^{\circ} \mathrm{C}$ for $14 \mathrm{~h}$ and the specimen of AA7075 aged at $150^{\circ} \mathrm{C}$ for $14 \mathrm{~h}$ have the highest roughness. As for the original specimens, they exhibited the lowest levels of roughness.

The surface roughness of the overaged specimen was higher than that of original specimen and lower than that of two alloy specimens exposed to the aging treatment. The AFM images obtained within the scope of the explanations complied with the tensile and microhardness tests. Figure 3 below illustrates the AFM analysis carried out on the surfaces of the specimens processed by aging and overaging treatment in the AA7075 alloy.

Figure 3 illustrates the AFM images, which show that aged and overaged specimens' phases have a homogeneous distribution. Grain size of the aging specimen is smaller than the overaged specimen. The AFM image confirms that the grain size increases after the overaging treatment.

Microhardness. Depending on temperature and time, the hardness values of the specimens aged at three different temperatures (AA6061 alloy: 140, 185, and $220^{\circ} \mathrm{C}$ and AA7075 alloy: 120,155 , and $\left.185^{\circ} \mathrm{C}\right)$ for five different periods of time $(1,4,10,14$, and $24 \mathrm{~h}$ ) are illustrated in Fig. 4. Significant increases in hardness values of the specimens depending on aging temperature and time were observed. The highest hardness value for the AA6061 alloy was obtained with the aging treatment conducted at $185^{\circ} \mathrm{C}$ for $14 \mathrm{~h}$ as $104 \mathrm{HV}$ value. The hardness value of the AA6061 alloy before applying any heat treatment was measured as $38 \mathrm{HV}$. In the AA6061 alloy, $\mathrm{Mg}_{2} \mathrm{Si}$ intermetallic compounds provide increased precipitation strengthening $[10,18,20]$. These intermetallic precipitates are incoherent with the main structure, and affect mechanical and physical properties of the material. In this process, the second phase is precipitated within the matrix phase. Precipitation of a new precipitate due to period and temperature from supersaturated solid solution resulted in an increase in the hardness and strength values. 


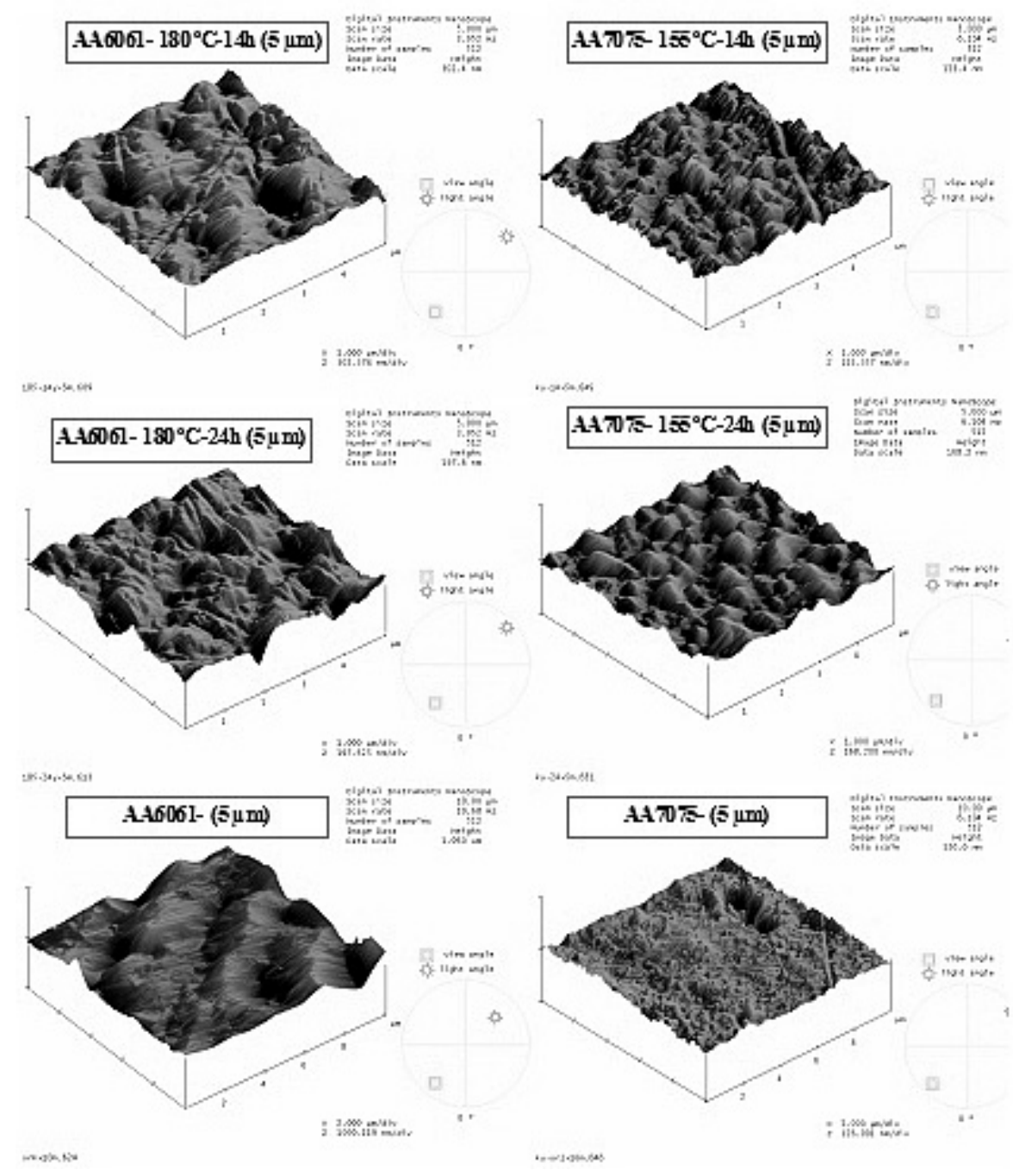

Fig. 2. The analysis of the aging treatment effect on surface roughness with the AFM image.

As for the AA7075 alloy, the highest hardness value was obtained at the aging treatment conducted at $150^{\circ} \mathrm{C}$ for $14 \mathrm{~h}$ as $210 \mathrm{HV}$ value. As stated in the literature, the reason behind the increase in hardness value of the AA7075 alloy is the $\mathrm{Mg}_{2} \mathrm{Zn}$ and $\mathrm{Al}_{2} \mathrm{CuMg}$ intermetallics, which are the hard secondary phases [19].

In conclusion to the study carried out on an AA6061 specimen, Demir [11] reported the hardness value as $56 \mathrm{HV}$. At the end of an aging process carried out at $185^{\circ} \mathrm{C}$ for $14 \mathrm{~h}$, it was reported that the hardness value increased to $106 \mathrm{HV}$. Maamar [21] reported that the hardness value for the AA7075 alloy increased from 145 to $185 \mathrm{HV}$ after applying the aging treatment. By comparing these results with other studies, it becomes obvious that the aging treatment is successful.

Tensile Test. Figure 5 illustrates the tensile test graphs depending on temperature and time of aging. The tensile strength values were observed to increase at a certain point for both of the specimens with the aging time and temperature. While the tensile strength of the AA6061 original specimen was about $2.1 \mathrm{MPa}$, it increased to about $4.5 \mathrm{MPa}$ as a result of the aging treatment. The aging treatment process increases the tensile strength. Analysis of $\%$ elongation values shows that there is a decrease in the AA6061 alloy. This result 

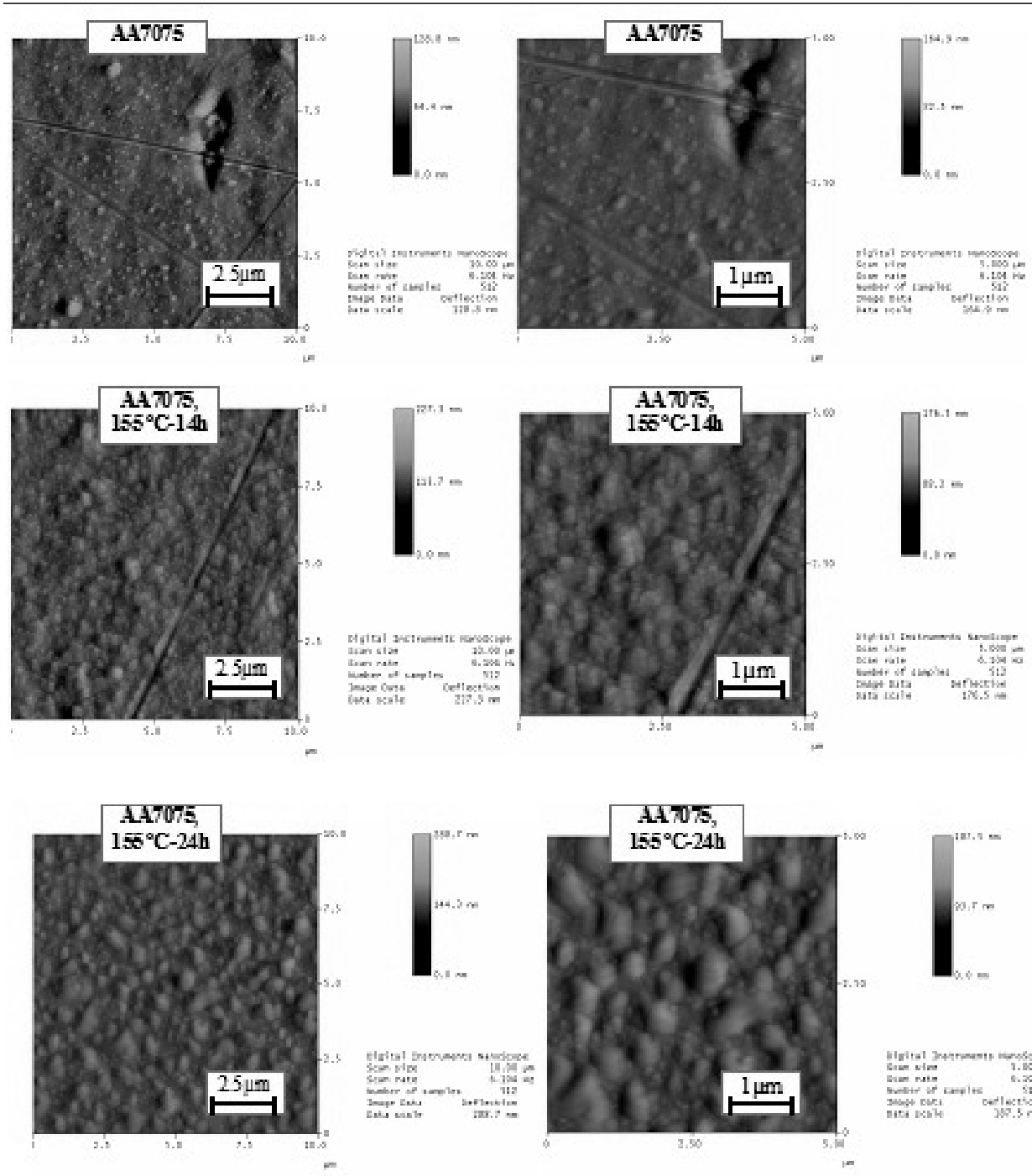

Fig. 3. Surface images of aged and overaged specimens of AA7075 taken the AFM.

indicates that the strength development was achieved without having a decrease in ductility with the aging treatment. The aging process does not affect the ductility.

Tensile strength of the AA7075 specimen, increase from 8.5 to $9.18 \mathrm{MPa}$ as a consequence of the aging treatment. As for the AA7075 specimen, the elongation values exhibited a decrease.

Fracture. Figure 6 shows the SEM images of the fractured surface taken from the fractured tensile test specimen. When the SEM images of the fractured surfaces were analyzed, the AA6061 original specimen exhibits a ductile fracture. The ductile dimples and network structures were determined to be dominant in the images. Examination of the fractured surface images of the aged specimens, the ductile dimples were determined to form at lower amounts. The SEM images of the fractured surfaces matched with the obtained tensile graphs.

As for the AA7075 specimen, a more brittle fracture was determined. It was also established from the SEM images that the AA7075 specimen exhibited more brittle fracture than the AA6061 specimen. The reason behind this was associated with the fact that while 

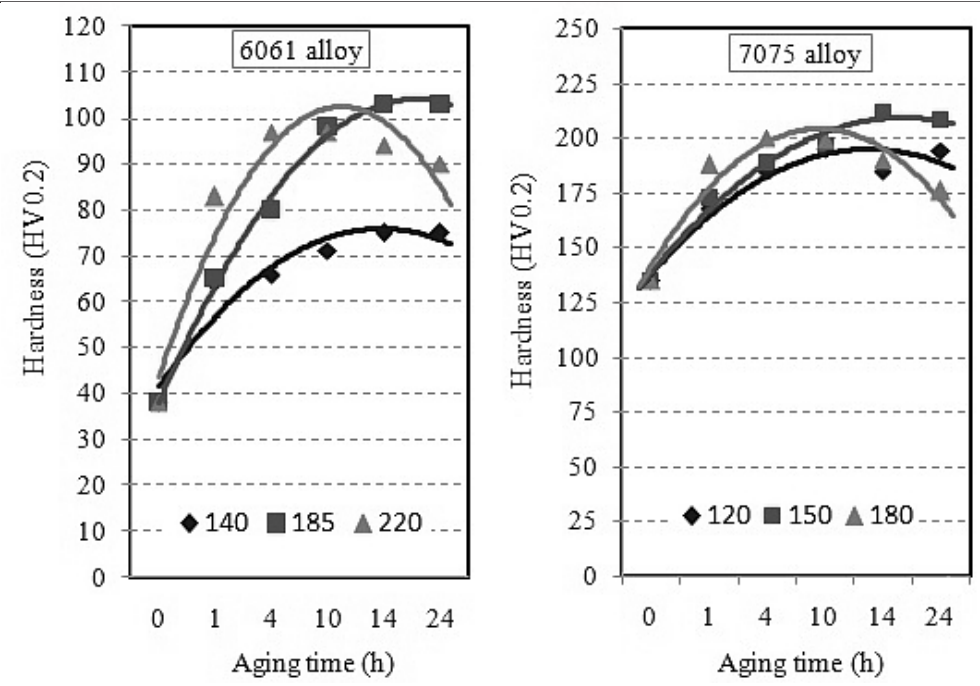

Fig. 4. Hardness measurements for various aging conditions.
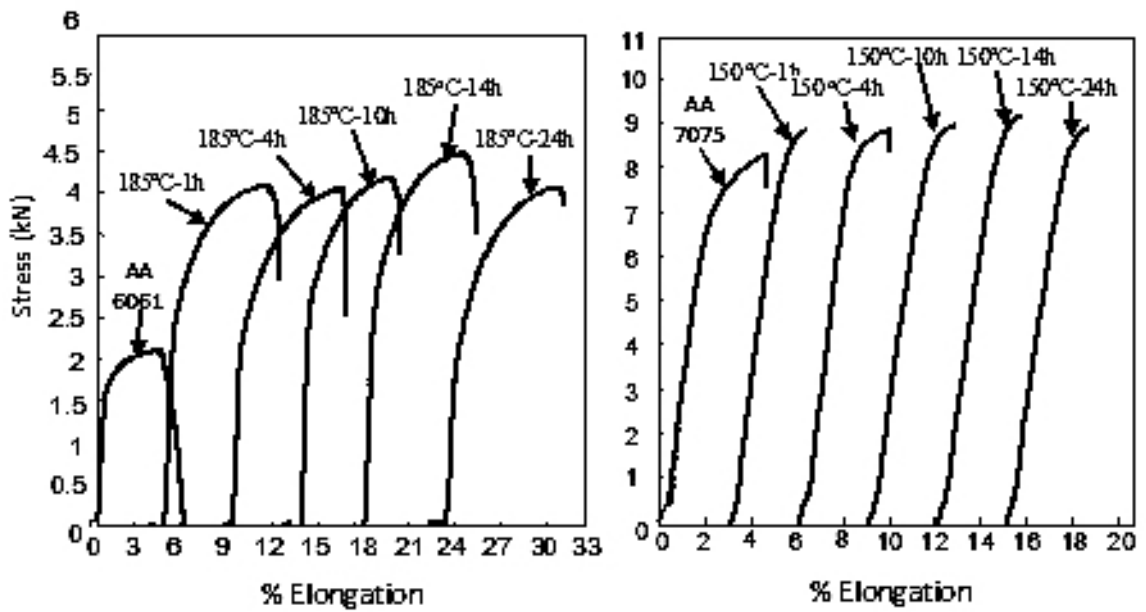

Fig. 5. The tensile test graphs of the specimens aged at various periods of time and temperatures.

the AA6061 specimen is a medium-strength Al alloy, the AA7075 specimen is a highstrength alloy.

Conclusions. In this study, commercial AA6061 and AA7075 alloys were aged, and the effect of aging time and temperature on mechanical and surface properties was determined. The following conclusions were drawn from the study:

It was determined that the AA7075 alloys have higher hardness values than the AA6061 alloys. At the end of the aging treatment it is observed that hardness of the AA7075 and AA6061 alloy increase to 190 and 104 HV hardness values, respectively.

In the aging treatments conducted in the study, it was obtained that the highest tensile strength was at $180^{\circ} \mathrm{C}$ for $14 \mathrm{~h}$ for the AA6061 alloy, whereas it was at $155^{\circ} \mathrm{C}$ for $14 \mathrm{~h}$ for the AA7075 alloy. The tensile strength increased about 3 times in the AA6061 alloy. This result proved that the aging treatment is successful.

As a result of the AFM analysis, the surface roughness of the as-received AA6061 and AA7075 alloys were determined to have the lowest value. On the other hand, the aging treatment was determined to increase the roughness. As for the overaged specimen, the roughness was determined to be higher than that of the aged specimen. 


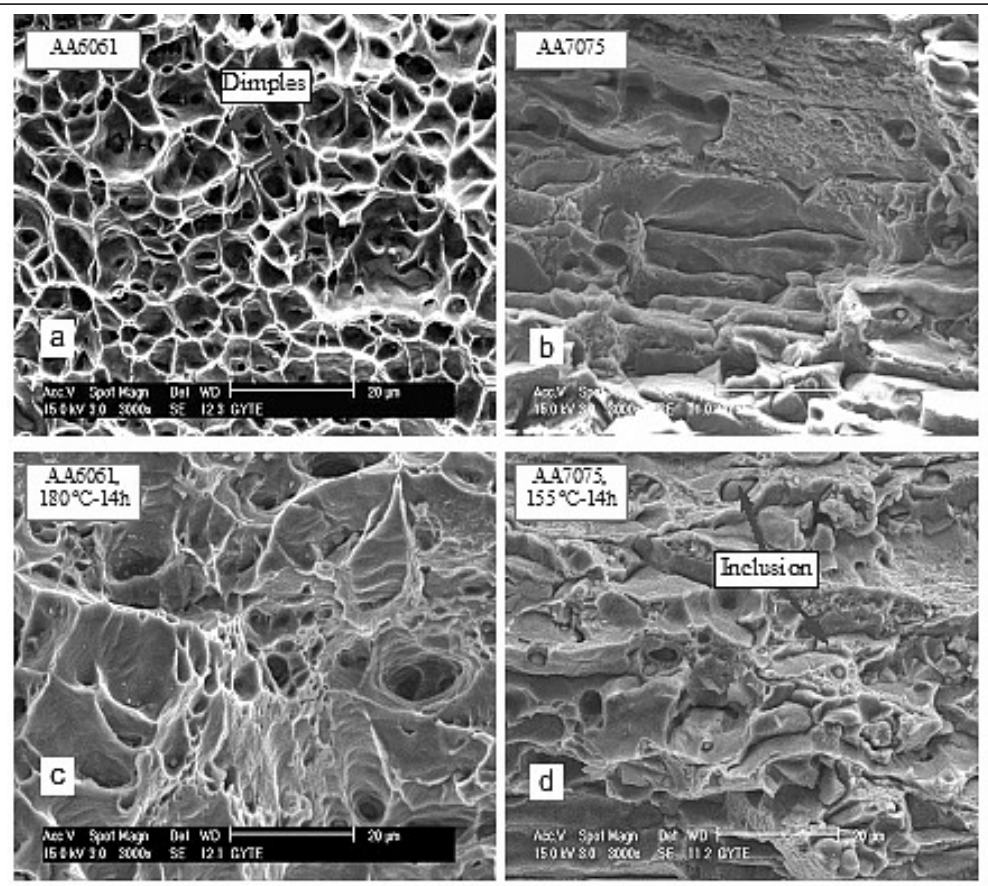

Fig. 6. The SEM images of the fractured surface of the specimens.

1. From the SEM images of the fractured surfaces, it was revealed that the as-received AA6061 alloy had ductile fracture, the dimples decreased in some parts of the specimen exposed to the aging treatment, and partly a brittle fracture occurred. The fracture behavior of the as-received AA7075 sample was determined to be more brittle than that of the as-received AA6061 alloy.

2. Aging and overaging specimens' phases have a homogeneous distribution.

3. Grain size of the aged specimen is smaller than that of overaged one.

4. The grain size increases after the overaging treatment.

5. For AA6061 alloy aging treatment process increases the tensile strength.

6. For AA7075 alloy aging treatment process does not affect the ductility.

\section{Резюме}

Досліджено вплив процесу старіння на шорсткість поверхні і механічні властивості алюмінієвих сплавів АА6061 та АА7075. Механічні властивості досліджували при випробуваннях на мікротвердість і розтяг. Поверхню зразків досліджували за допомогою рентгеноструктурного аналізу. Після випробувань на розтяг поверхню руйнування досліджували методом растрової електронної мікроскопії. Вплив процесу старіння на шорсткість поверхні вивчали за допомогою атомно-силового мікроскопа. Показано, що з ростом шорсткості поверхні збільшується кількість виділених фаз.

1. N. Yazdian, F. Karimzadeh, and M.Tavoosi, "Microstructural evolution of nanostructure 7075 aluminum alloy during isothermal annealing," J. Alloys Compounds, 493, 137-141 (2010).

2. F. Hayat, "The effects of the welding current on heat input, nugget geometry, and the mechanical and fractural properties of resistance spot welding on $\mathrm{Mg} / \mathrm{Al}$ dissimilar materials," Mater. Design, 32, 2476- 2484 (2011). 
3. Y. B. Yan, Z. W. Zhang, W. Shen, et al., "Microstructure and properties of magnesium AZ31B-aluminum 7075 explosively welded composite plate," Mater. Sci. Eng. A, 527, 2241-2245 (2010).

4. W. S. Miller, L. Zhuang, J. Bottema, et al., "Recent development in aluminium alloys for the automotive industry," Mater. Sci. Eng. A, 280, 37-49 (2000).

5. J. F. Li, Z. W. Peng, C. X. Li, et al., "Mechanical properties, corrosion behaviors and microstructures of 7075 aluminium alloy with various aging treatments," Trans. Nonferrous Metals Soc. China, 18, No. 4, 755-762 (2008).

6. T. Wang, Z. M. Yin, and K. Shen, "Single-aging characteristics of 7055 aluminum alloy," Trans. Nonferrous Metals Soc. China, 17, No. 3, 548-552 (2007).

7. H. Kaya, "Dependence of electrical resistivity on temperature and composition of Al-Cu alloys," Mater. Res. Innov., 16, No. 3, 224-229 (2012).

8. T. Szymczak, Z. Kowalewski, and L. Dietrich, "Experimental analysis of creep and fatigue of light multifunctional aluminium alloys," Mater. Res. Innov., 15, No. 1, 53-56 (2011).

9. Z. Yang, J. P. Li, J. X. Zhang, et al., "Review on research and development of magnesium alloys," Acta Metall. Sinica, 21, 313-328 (2008).

10. G. Das, M. Das, S. Ghosh, et al., "Effect of aging on mechanical properties of 6063 Al-alloy using instrumented ball indentation technique," Mater. Sci. Eng. A, 527, 1590-1594 (2010).

11. H. Demir and S. Gündüz, "The effects of aging on machinability of 6061 aluminium alloy," Mater. Design, 30, 1480-1483 (2009).

12. D. G. Altenpohl, Aluminum: Technology, Applications and Environment: A Profile of a Modern Metal, 6th edition, Wiley (1998).

13. L. P. Troeger and E. A. Starke, "Microstructural and mechanical characterization of a superplastic 6xxx aluminum alloy," Mater. Sci. Eng. A, 277, 102-114 (2000).

14. S. J. Murtha, "New 6XXX aluminum alloy for automotive body sheet applications," SAE Int. J. Mater. Manufact., 104, 657-666 (1995).

15. S. D. Liu, Y. Zhang, W. J. Liu, et al., "Effect of step-quenching on microstructure of aluminum alloy 7055," Trans. Nonferrous Metals Soc. China, 20, No. 1, 1-6 (2010).

16. T. Wang, Z. M. Yin, and K. Shen, "Single-aging characteristics of 7055 aluminum alloy," Trans. Nonferrous Metals Soc. China, 17, No. 3, 548-552 (2007).

17. J.-F. Li, Z. W. Peng, C. X. Li, et al., "Mechanical properties, corrosion behaviors and microstructures of 7075 aluminum alloy with various aging treatments," Trans. Nonferrous Metals Soc. China, 18, No. 4, 755-762 (2008).

18. F. Ozturk, A. Sisman, S. Toros, et al., "Influence of aging treatment on mechanical properties of 6061 aluminum alloy," Mater. Design, 31, 972-975 (2010).

19. H. Khalid Rafi, G. D. Janaki Ram, G. Phanikumar, and K. Prasad Rao, "Microstructure and tensile properties of friction welded aluminum alloy AA7075-T6," Mater. Design, 31, 2375-2380 (2010).

20. A. Meyveci, I. Karacan, U. Caligülü, and H. Durmus, "Pin-on-disc characterization of 2xxx and 6xxx aluminium alloys aged by precipitation age hardening," J. Alloys Compounds, 491, 278-283 (2010).

21. H. Maamar, R. Rabah Otmani, T. Fahssi, et al., "Heat treatment and welding effects on mechanical properties and microstructure evolution of 2024 and 7075 aluminium alloys," Metal (Hradec nad Moravici), 13-15.5.2008, 1-7 (2008). 